\title{
Research and Practice on Innovation Personnel Training Pattern of Energy and Power Profession for application - oriented Undergraduate Colleges
}

\author{
Xu Youning, Guan Duojiao, Li Jing, Shi Junrui \\ Dept. of Energy and Power Engineering \\ Shenyang Institute of Engineering \\ Shenyang, China \\ silver_gdj@163.com
}

\begin{abstract}
In view of the existing main problems of current application-based talents training and combined with the power and energy industry requirements, an innovation personnel training pattern of energy and power profession for application - oriented undergraduate colleges was put forward. Taking Shenyang Institute of Engineering as the case, the training pattern of application-based talents was explored and practiced. It includes the constructing of new courses and practical teaching system, the reform of teaching methods, innovation of teaching methods, construction strengthening of teaching team, promotion of the cooperation among production, learning and research and so on.
\end{abstract}

Keywords-Energy and power; Personnel Training Pattern; Application - oriented Undergraduate; Innovation

\section{INTRODUCTION}

The advancement of science and technology as well as the development of social economy are in urgent need of innovative talents of higher education training. Innovation personnel training pattern is the key problem. Through the emancipation of the mind and renewing of the idea, the students' innovation consciousness can be cultivated, innovative thinking can be trained, multi-subjects amalgamation can be strengthened. Accordingly a new personnel training system can be established which is accord with the improvement of students' innovate capability. Just because of this, this point is emphasized in "The national medium and long-term education reform and development plan outline (2010)" about the work of personnel training in colleges and universities in China. As a application-based undergraduate college, energy and power department of Shenyang Institute of Engineering has done some exploration and reform on the personnel training pattern and its realization problem according to local and professional talented person's demand.

\section{PROBLEMS OF APPLICATION-BASED TALENTS TRAINING}

A. The lack of clear scientific positioning on the target of talent education.

In China, many local undergraduate colleges are upgraded by the vocational level colleges which task is application-based talents training. It is different from the academic (or base type) talent; It is also different from the skilled talents. It pays more attention to the ability of solving the actual problem in production or practice work with professional theory knowledge. It stressed the coordinated development of theory, knowledge, method and ability. In a word personnel training goal should also have different layers according to different levels of higher education.

\section{B. "Training as profession" makes the limitation of knowledge}

"Training as profession" makes the limitation of knowledge, which dissatisfies the enterprise requirements of diversifying talents. It is rarely outside the professional knowledge in this pattern, which take the profession as the core in enrolling and training. It is also rarely related with other professional or other fields' knowledge and have no interdisciplinary cross, seepage among different subjects. This pattern does not fit in with the social economy development, which need diversified talents more and more. It is also mismatch the undergraduate students training goal of "wide range of knowledge, solid background, strong ability, high quality", which was presented by Chinese Ministry of Education.

\section{In professional Settings and curriculum system construction, it is still according to the subject system and theoretical knowledge is overweight.}

At present in China, application-based education curriculum is mainly according to the logic of the discipline structure. It has put too much emphasis on the systematic and integrity of knowledge. This curriculum pattern based on the subject, although can provide students with theory foundation, could not provide the key procedural work knowledge and the basic work experience. Thus the course content and practical work has a rift and lax communication.

D. Wrongly to think that the practice teaching system belongs to the theoretical knowledge system and not to strengthen students' practical ability.

Take our energy and power engineering department as an example, Practice Training lays on basically demonstration, observation and validation due to a lot of practice classes are arranged in curriculum teaching process. Students are lack of practical skills to solve practical 
problems, especially the lack of innovation ability, which is often exposed in the graduation design stage.

\section{CLEAR DEFINITION OF TALENTS TRAINING OBJECT AND REFORM OF TALENT CULTIVATION PATTERN}

Personnel training must first clear the talent cultivation object and talent cultivation pattern. In our department energy and power engineering advantage prominent. The cultivation object oriented to the market and professional orientation has an international standards. We provide application-based engineering and technical talents for energy and electric power industries, equipment manufacturing industries. As for my department, we have thermal energy and power engineering profession, building environment and equipment engineering profession, wind energy and power engineering profession, nuclear engineering and nuclear technology profession. Any application-based engineering and technical talents of above four professional groups will be engaged in its professional fields or other related fields work such as design with closely related equipment, manufacture, installation, commissioning, operation, maintenance, management and service work. So we must take " high-quality practical talents having comprehensive system engineering consciousness, practical and realistic engineering quality, comprehensive engineering knowledge structure, strong engineering practice ability, independent knowledge achievement " as the common talents training target.

For the reform of talents training pattern it is mainly concentrated in the following several aspects: (1) It need a deep integration and optimization on theory teaching system and practical teaching system of different direction profession based on the basic requirements of talents training and constructing of modular teaching system (2) It needs to adjust the curriculum of the theory knowledge system, which is based on the professional basic knowledge and moderately broaden the students' professional knowledge to meet the students' future development needs, especially to meet students' employment needs. All of this will lay a solid professional theoretical basis for the student's transformation from single professional talents into multiplex talents. (3) It needs to deepen and widen the practice teaching system and practice teaching content. We can make the students master the basic experiment validate content from the whole engineering training quality. We can make the students master the basic experiment validate content by personalized engineering training. We will try to make students participate in scientific research training and scientific research projects and the development new experiments in practice. So we can realize "validate" to "comprehensive" and to "design" process. (4) It needs the organic fusion of the course content and teaching resources whose objects have the same or similar part. It also needs to build a basic course platform of common professional categories for different related profession direction talent training. This module type of talent training pattern framework is shown as "Fig. 1".

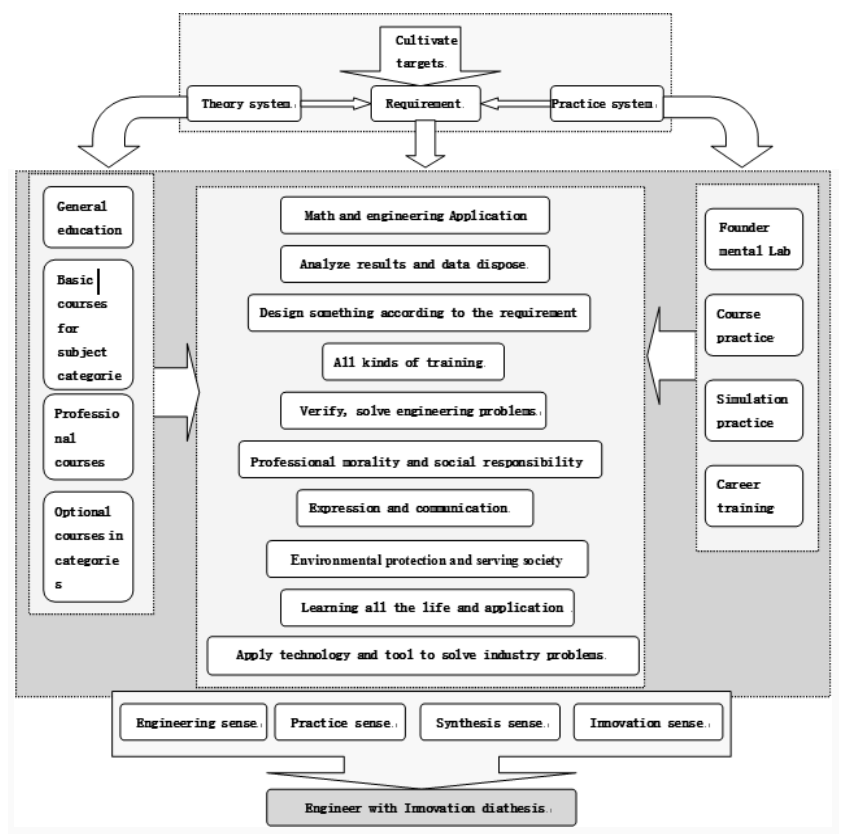

Figure 1 Module Type of Talent Training Pattern Framework

\section{REALIZATION OF CULTIVATION MODE FOR TALENTS}

In the practical application of the cultivation of innovative talents, according to the need of energy and power occupation group and the market economy for talents, the basic requirements of group (ability), clear training objectives, and the training mode of "one main line, two systems, three platform" are proposed. The frame structure considering both the common basis of the professional direction of the occupation group, and the professional direction characteristics, which are the bases we build module and set curriculum on. To achieve the optimal goal of cultivating talents, dynamic adjustment of every module proportion according to the needs of related requirements and the market share. A main line is to "cultivate applicationoriented engineers", which running through the whole process of personnel training system; two systems are the "practical teaching system and the theoretical teaching system", two system is relatively independent, mutual support. The three level is the "general education platform, subject categories based education platform and professional (direction) technology education platform". For example with the construction of our professional group, they belong to the same professional background of energy science, energy engineering, which makes them share the first two platform resources, play down the concept of professional direction, and benefit cultivating students "pan-engineering" consciousness, so that each professional scope can be extended on the basis of the existing. 


\section{A. Curriculum Innovation}

- Dynamic adjusted curriculum system in the module and the proportion of each module in the teaching. Curriculum content should be sensitive, dynamic, open and reflect the progress of science and technology and social development reality, take the latest achievements of subject development as important option for the course content, which follows the clues, the general curriculum focuses on training students a solid foundation of knowledge; basic courses in general focus on the knowledge base on building a generous, broaden knowledge; professional platform and professional courses is to develop students professional knowledge and ability of innovation; optional courses is wide and state - of - the - art. Integration and optimization of the course module must be systematic, to construct the curriculum content, so as to ensure the training specifications and quality.

- Integrated the professional knowledge into the whole course system. In the curriculum, "Professional Introduction" and " The power plant introduction" courses were taken as a professional cognitive course, and the "Professional Introduction" course was set to the first and second semester freshmen, so that a basic understanding of professional courses; while " The power plant introduction" was set to the third and fourth semester, with progressive teaching arrangement for the professional knowledge. Enable the students owning a clear understanding to the professional before learning basic courses and general courses, do have clear learning objectives.

- Arranged Extracurricular, and blended organically with the cultivation target. Establish the second classroom, in which the professional introduction and basic requirements of professional engineer quality should be grasping for the grade one or two students. And the assessment was followed by counselors. At the mean time, they should also carry out the social responsibility and occupation education, the organic integration of the ideological and moral course between curricular and extracurricular, through independent organization, participate in various activities, to cultivate the students practice ability. Offered a wide variety of optional courses for grade three or four, students could choose elective courses according to their own interest and the relevant laboratory research projects arranged, which training students to solve practical problems and the ability of innovation.

- Integrated the industry standard and general engineering standards in the course. In the course, the relevant industry standards and engineering standards should be timely replenishment, updated, and the standard clauses should also be explained the reason and significance of; to discuss the curriculum design and the theme in the form of learning, to enable students to learn the latest engineering knowledge and professional knowledge.

\section{B. Practice teaching system reform}

The practice teaching content should not only consider the continuity and sustainability in the design, satisfy requirements of industries and enterprises for talents of practical skills, definitely cultivate talents with advanced knowledge and advanced skills, but also to ensure that the practice teaching carrying out smoothly. With systematic view and reasonable arrangements for various practical link experiment and engineering practice, the formation of new teaching system, as shown in the following "Table I".

TABLE I. PRACTICE TEACHING SYSTEM

\begin{tabular}{|c|l|l|l|}
\hline \multicolumn{1}{|c|}{$\begin{array}{c}\text { Basic skills } \\
\text { training }\end{array}$} & $\begin{array}{l}\text { Basic engineering } \\
\text { skills, use of } \\
\text { commonly used } \\
\text { thermal instrument }\end{array}$ & $\begin{array}{l}\text { intermediate } \\
\text { Thermal measurement } \\
\text { and basic skill training }\end{array}$ & $\begin{array}{l}\text { advanced test and } \\
\text { training technology, } \\
\text { virtual instrument, } \\
\text { engineering }\end{array}$ \\
\hline $\begin{array}{c}\text { General design } \\
\text { training }\end{array}$ & $\begin{array}{l}\text { Open, integrated } \\
\text { experimental system } \\
\text { design, experimental } \\
\text { results analysis } \\
\text { training }\end{array}$ & $\begin{array}{l}\text { Medium-sized } \\
\text { comprehensive subject } \\
\text { for thermal system design } \\
\text { training based on } \\
\text { equipment }\end{array}$ & $\begin{array}{l}\text { comprehensive } \\
\text { thermodynamic } \\
\text { system (equipment) } \\
\text { and simulation } \\
\text { training design the } \\
\text { construction } \\
\text { focuses on virtual } \\
\text { laboratory }\end{array}$ \\
\hline $\begin{array}{l}\text { design } \\
\text { Development } \\
\text { and operation } \\
\text { training } \\
\text { Combined with } \\
\text { practical project }\end{array}$ & $\begin{array}{l}\text { Design and } \\
\text { development of small } \\
\text { topic with certain } \\
\text { function }\end{array}$ & $\begin{array}{l}\text { comprehensive design } \\
\text { course training and } \\
\text { participating in practical } \\
\text { application Combined } \\
\text { with science and } \\
\text { technology innovation } \\
\text { and competition of } \\
\text { national college students }\end{array}$ & $\begin{array}{l}\text { Participating of } \\
\text { research projeds, } \\
\text { and enterprises } \\
\text { supervisor and } \\
\text { management, } \\
\text { preliminary training } \\
\text { of scientific } \\
\text { research ability. }\end{array}$ \\
\hline
\end{tabular}

The following are specific reform measures:

- Centralized construction of practice teaching platform - power engineering practice teaching center. In order to create concentrated practice teaching training environment of professional knowledge and engineering quality, power engineering practice teaching center is constructed. This center includes four parts: teaching laboratory, simulation center of plant operation, installation and maintenance of thermal practice factory, scientific research of provincial key laboratory. Students can have the training practice and innovation ability training at different stages, different levels and functions

- Integration of Production, learning and research. Based on scientific research projects, provincial key laboratory and engineering practice center, students' professional ability was trained. By the influence of industry advantage, combined with relevant research institutes and enterprises, students' professional engineering quality and innovation ability are developed in the cultivation of enterprise production, teaching and scientific research. The fourth grade students can order training mode according to the enterprise needs, according to the employment situation. They can also partially adjust training scheme, strengthen the special ability training.

- Strengthen experimental teaching course hours and contents based on the realization of the experiment 
content and realize the progress from "confirmation" to "comprehensive" and "design". In-class experiments require to design new experiment content and to construct comprehensive experimental platform based on the current experimental conditions. At the same time, teachers are required to increase theory structure part and the operation part of the teaching content in the laboratory or training base and do comprehensive thermodynamic system equipment simulation training by use of the thermal power plant virtual laboratory.

- Increasing the professional design content and new achievements in scientific research in the process of teaching. Students can learn a number of relevant and professional knowledge of the technical invention patent and results. These results are related to the products, laboratory equipment and measurement platform. Let the students know from experience he innovation achievement effect in the experimental device and platform by operation. The teacher will introduce the background and ideas of the invention, so as to let the students experience the process and the benefits of scientific research, strengthen the interest of innovation.

- Engineering practice teaching in various forms. Training contracts have been signed with a number of power plants. It takes 3 weeks for students to practice in different plant. Rest of the practice content are set for simulation machine in Power Engineering Center and for the installation and maintenance in practice factory .Training plan was made by college and enterprises and enterprises give students assessment and guidance.

- Organize students to participate in science and technology competition for college students. On the basis of the achieved two or three prize in national energy-saving emission reduction competition, a variety of activities in science and technology competition were organized, in which the students practical ability and innovation ability were cultivated and trained. It also enhances the teacher's ability in guiding students practice.

\section{Teaching method reform}

- Learning by interest guidance. For low grade students professional education was arranged by laboratory visiting, professional content understanding, development trend learning. Handson operation conditions are also provided, to increase their professional knowledge learning interest. Laboratory is opened for the second grade students, to excite their further study interest.

- The application of teaching method to promote the integration of theory and practice. We strengthen the training of application ability and understanding of knowledge by combining theories with subject curriculum design, which oriented to the goal of Systematic, overall cognitive knowledge system.
Discussion was carried with practical problems as the topic of curriculum design, which is done good to the students' ability training.

- The use of "stratified teaching" method in professional skills courses, and combines the basic theory and new technology. "one" knowledge include basic concepts, theories, the main structure of the equipment, common sense of systems and equipment operation; "two" knowledge is mainly analysis, fault equipment excluded means, the main rules of equipment operation, which is used for training students in the job skills required; "three " knowledge focus more on quantitative calculation and analysis methods, advanced technology and other content, which is used for training students' ability of analyzing and solving problems, expanding professional perspective.

\section{Curriculum evaluation method reform}

In the evaluation of learning effect, make reasonable use of network teaching platform and integrate practice examination means. This evaluation method can help students grasp and use the basic theory and basic skills. Students' comprehensive ability was overall evaluated. In the examination, capability assessment and combination of theory and practice were emphasized, so as to promote the students' understanding and application of knowledge. According to the characteristics of the course, different classes were set with different assessment methods.

\section{E. Teaching team construction}

- Strengthen the training of professional engineering capability. We will send 2-3 teachers to power enterprise each year. We also complete some projects combined with enterprises. Enterprises are responsible for the guidance of teachers and eventually form project engineering team that can solve practical problems.

- The cultivation of scientific research ability in practice. By using the provincial key laboratory, the two existing research platform of key laboratory of Shenyang city, we support the young teachers to declare research projects. We also select outstanding teachers to have cooperation work with our professional domestic and foreign well-known colleges and universities. At the same time we invite domestic and foreign well-known professor as a visiting professor in my professional, to give lectures and scientific cooperation.

- The introduction of as part-time teachers. In the teaching process, for the boiler combustion, boiler, steam turbine operation site targeted course, we employ some practical and technical talents as parttime teachers. They come from Institute of Liaoning province electric power simulation center and national power plant combustion technology engineering center and so on. 
- Encourage young teachers to guide the students to participate in science and technology competition for college students. Set the incentive policy, arrangements for the annual $2 \sim 3$ young teachers as technology contest for college students, improve the young teachers ability, adapt to the requirement of fostering the talents.

In recent years, through the implementation of the above measures, a good teaching staff has been set up, which is suitable for training applied talents. This staff has a strong practical ability, engineering innovation ability, teaching ability, high professional quality and is fit to the professional and technical development. They are the teaching staffs that we need.

\section{CONCLUSION}

In our college energy and power engineering profession is based on thermal energy and power engineering, which are as the core of the professional group. After decades of construction and development, teaching conditions, teaching staff and experimental conditions are all on a new level. In the northeast of China, and even in the national electric power industry, we have made a major contribution on personnel training and technical service, which has obtained the fully affirmation. Our college has been one of the 6 universities and colleges with undergraduate course oriented to power industry by State Grid in 2012. Innovation personnel training pattern of energy and power profession for application - oriented undergraduate colleges can systematized knowledge system, diversified channels of employment; It can also realize the progressive type ability training of students and the integration of theory with practice; It can integrate teaching resources, improve the quality of teaching and school level; It can strengthen professional group construction, improve the professional construction level and quality. With the rapid development of national economic construction, more and more higher demands were put forward for electric power college. While personnel training is the critical problem. By constructing new personnel training pattern with energy and power engineering characteristics, the optimal and the most reasonable way to realize the cultivating goal for applied undergraduate colleges is gradually explored.

\section{REFERENCES}

[1] Zhang Fenghua, Ni Zhengshun, Shao Jun, etc. Innovation and Practices of Talents Training Mode for Application-Oriented Undergraduate Based on Innovation Diathesis Education[J].Packing Journal,2010(1):85-89.

[2] Gu Tianlong, Jing Xinxing, Guo Qing, etc., A Research on the Training Mode Reform of College Engineering Practical TalentsReflections on Electronic Information Engineering Practical Talents'Experimental Zone at Guilin University of Electronic Technology[J]. China Higher Education Research, 2012(1).

[3] RUAN Xie-yong, JIANG Sheng-yong, ZHU Min-jie.The Mode of Cultivating Application-oriented Engineering Talents in Local Universities[J]. ,Research and Exploration in Laboratory, , 2012(2).

[4] Zhao Qiao. A research on talents cultivation mode of local application-oriented university[J]. Journal of Henan Institute of Science and Technology, 2012(4).

[5] Dai Bo, Ji Wengang, Liu Jiandong, etc. Innovation Practice of Ladder Training Model of Engineering Application Ability[J]. Higher Engineering Education,2011(6):136-140.

[6] Zuo Zhiyuan, Yang Xiaoxi. On the specialty construction of thermal energy \& power engineering under low-carbon economy[J].Journal of Dong guan University of Technology,2011(11)

[7] Liu Huizhou. The Exploration of Training Mode for Cultivating Students' Practical Ability and Applied Ability_— Taking Tonghua Normal University as an Example[J]. Modern Education Management, 2012(10).

[8] XU Shu-Hui, QIN Wei-Nian. On the Paradigm for Cultivating Applied Talents in Local Colleges [J].Journal of Guangxi University for Nationalities(Philosophy and Social Science Edition), 2012(5).

[9] Liu Mingjiu,Li Youyong,Chang Jingling, etc. The practice of training innovative talents by the cooperation of colleges and enterprises and its reflection [J]. Journal of Henan Institute of Science and Technology. 2010(04).

[10] Guo Lei. Excellent engineer training program under the heat and power engineering education reform and professional practice[J].Hunan Agricultural Machinery,2011(11). 